\title{
A Comparative Study of Efficacy of Outcome of Lateral Internal Sphincterotomy versus Subcutaneous Fissurectomy in Chronic Fissure in Ano
}

\author{
Suryanaryana Reddy V${ }^{\oplus 1}$, Ravindra Prasad B ${ }^{\circledR 2}$, Ram Mohan C ${ }^{1}$, Vamshi Chandra B ${ }^{\circledR 3}$, Satya Dev ${ }^{\oplus 1}$ \\ ${ }^{1}$ Professor, Department of General Surgery, Chalmeda AnandRao Institute of Medical Sciences, Karimnagar, Telangana, India, ${ }^{2}$ Assistant Professor, Department of \\ General Surgery, Chalmeda AnandRao Institute of Medical Sciences, Karimnagar, Telangana, India, ${ }^{3}$ Resident, Department of General Surgery, Chalmeda AnandRao \\ Institute of Medical Sciences, Karimnagar, Telangana, India.
}

\section{Abstract}

Background: Fissure-in-ano is a very common problem across the world which causes considerable morbidity and affects the patient's quality of life to a greater extent. Anal fissure is a common painful condition affecting the anal canal. The main aim of study was to compare the efficacy of outcome of subcutaneous fissurectomy versus lateral internal sphincterotomy in chronic fissure in Ano. Subjects and Methods: The study was a prospective, parallel group, comparative trial. The study was conducted at Department of General Surgery, Chalmeda AnandRao Institute of Medical Sciences, Karimnagar. The number of patients included in the study was 50. Patients were divided into lateral internal sphincterotomy groups and subcutaneous fissurectomy groups. Patients were followed up regularly for relief of symptoms i.e., pain in the anal region and bleeding from anal region and for complications like incontinence; duration of sitz baths and number of work days lost. Results: The mean age group in the present study was $38.24 \pm 9.96$ for subcutaneous fissurectomy and $39.2 \pm 10.4$ for lateral internal sphincterotomy; there was no significant difference in the mean age in either of the groups with $\mathrm{P}$ value $>0.05$. Conclusion: The current study shows results in favor of subcutaneous fissurectomy with a healing rate of $100 \%$ with faster pain-relief and minimal or no complications if performed by the hands of an experienced surgeon.

Keywords: Lateral internal sphincterotomy, subcutaneous fissurectomy, anal fissure

Corresponding Author: Ravindra Prasad B, Assistant Professor, Department of General Surgery, Chalmeda AnandRao Institute of Medical Sciences, Karimnagar, Telangana, India.

E-mail: shanmugampt@rediffmail.com

Received: 11 December 2019

Revised: 10 January 2020

Accepted: 18 January 2020

Published: 26 May 2020

\section{Introduction}

Anal fissure is a common disorder, but its exact incidence is unknown. The condition may frequently be misdiagnosed as hemorrhoids by primary care providers. The clinical hallmark of anal fissure is pain during, and especially after, defecation. The pain may be short lived with acute fissures, but may last hours or even become continuous in chronic cases. ${ }^{[1]}$

Subcutaneous lateral internal sphincterotomy is the treatment of choice for chronic anal fissures. Sphincterotomy can be carried out using an open or a subcutaneous technique and under local or general anaesthesia. This procedure, however, has been associated with an overall risk of incontinence of about $10 \%$ in a systematic review of randomized surgical trials. ${ }^{[2]}$
The standard algorithm for anal fissure treatment has traditionally consisted of a trial of fiber supplementation, sitz baths, and topical analgesics. If the pain is intolerable or conservative care fails, surgery is performed (usually a lateral internal sphincterotomy/subcutaneous fissurectomy).

This study aim was to compare the efficacy of outcome of subcutaneous fissurectomy versus lateral internal sphincterotomy in chronic fissure in ano.

\section{Subjects and Methods}

\section{Study Design}

The study was a prospective, parallel group, comparative trial. Samplings 
The number of patients included in the study is 50 , Out of which 25 are in the test group and 25 are in the control group.

\section{Study Center}

The study was conducted at Department of General Surgery, Chalmeda Anand Rao Institute of Medical Sciences, Karimnagar from October 2016 to November 2018.

\section{Inclusion Criteria}

- Patients between 25 to 70 years

- Age of both sexes

- Patients of chronic fissure in ano.

\section{Exclusion criteria}

- Recurrent fissures

- Fissures with hemorrhoid's and fistula

- Fissure associated with malignancies

- Fissure secondary to specific diseases like tuberculosis, crohn's disease etc.

- Pregnant women

Group A: Patients were treated with lateral internal sphincterotomy.

Group B: patients were treated with subcutaneous fissurectomy

The patients were followed up for a period of 6 months and were evaluated for relief of symptoms. Observations were recorded at the end of 6 months following the treatment in a proforma designed for the purpose. Subcutaneous fissurectomy and Lateral internal sphincterotomy were performed by senior surgeons in the hospital.

Patients in both the treatment groups were prescribed standard treatment for fissure in the form of stool softeners, sitz bath and fibre diet. Also, the operated patients were treated with a single dose of a broad spectrum antibiotic at the start of surgery.

\section{Ethics approval}

This study was reviewed and approved by the institute ethics committee, CAIMS, Karimnagar. All patients gave written informed consent to be included.

\section{Statistical Analysis}

The data obtained was analyzed using SPSS software version 20.0. Appropriate statistical tests were used to compare subcutaneous fissurectomy and lateral internal sphincterotomy. Descriptive results are expressed as mean and SD of various parameters. Probability value ( $p$ value) was used to determine the level of significance, $p$ value $<0.05$ was considered as significant, $\mathrm{p}$ value $<0.01$ was considered as highly significant.

\section{Results}

In the present study it was observed that patients with chronic fissure were more common in the age group of 31-40 years. The mean age group in the present study was $38.24 \pm 9.96$ for subcutaneous fissurectomy and $39.2 \pm 10.4$ for lateral internal sphincterotomy; there was no significant difference in the mean age in either of the groups with $p$ - value $>0.05$ [Figure 1].

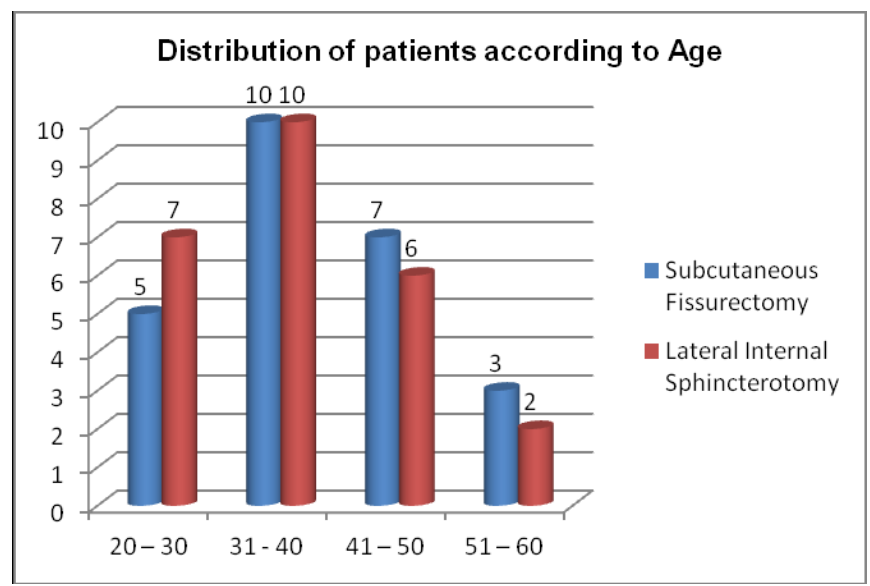

Figure 1: Age distribution of the patients

In the present study it was observed that the group which underwent subcutaneous fissurectomy had $60 \%$ males and 40 $\%$ females compared to $64 \%$ males and $36 \%$ females in the group which underwent lateral internal sphincterotomy. There was no statistical significance $(p>0.05)$ in gender wise distribution in both groups [Table 2]

\begin{tabular}{|lll|}
\hline Table 1: Gender distribution of the patients \\
\hline Gender & $\begin{array}{l}\text { Subcutaneous } \\
\text { Fissurec- } \\
\text { tomyNo } \\
\%)\end{array}$ & $\begin{array}{l}\text { Lateral Internal } \\
\text { Sphinctero- } \\
\text { tomyNo }(\%)\end{array}$ \\
Male & $15(60)$ & $16(64)$ \\
Female & $10(40)$ & $9(36)$ \\
\hline
\end{tabular}

The mean duration of symptoms in patients undergoing subcutaneous fissurectomy was $3.36 \pm 0.37$ and lateral internal sphincterotomy was $3.38 \pm 0.36$ there was no significant difference in duration of treatment in either groups. Pain was presenting symptom in $100 \%$ of cases in either groups [Table 2].

$64 \%$ of cases who underwent lateral internal sphincterotomy presented with constipation as one of the presenting complaint compared to $56 \%$ of cases who underwent subcutaneous 
Table 2: Comparison of symptom duration in both treatment arms

\begin{tabular}{lll}
\hline Duration & $\begin{array}{l}\text { Subcutaneous } \\
\text { Fissurec- } \\
\text { tomyNo ( \%) }\end{array}$ & $\begin{array}{l}\text { Lateral Internal } \\
\text { Sphinctero- } \\
\text { tomyNo ( \%) }\end{array}$ \\
\hline 3 months & $10(40)$ & $11(44)$ \\
\hline 3.5 months & $11(44)$ & $10(40)$ \\
\hline months & $4(16)$ & $4(16)$ \\
\hline Mean \pm SD & $3.36 \pm 0.37$ & $3.38 \pm 0.36$ \\
\hline
\end{tabular}

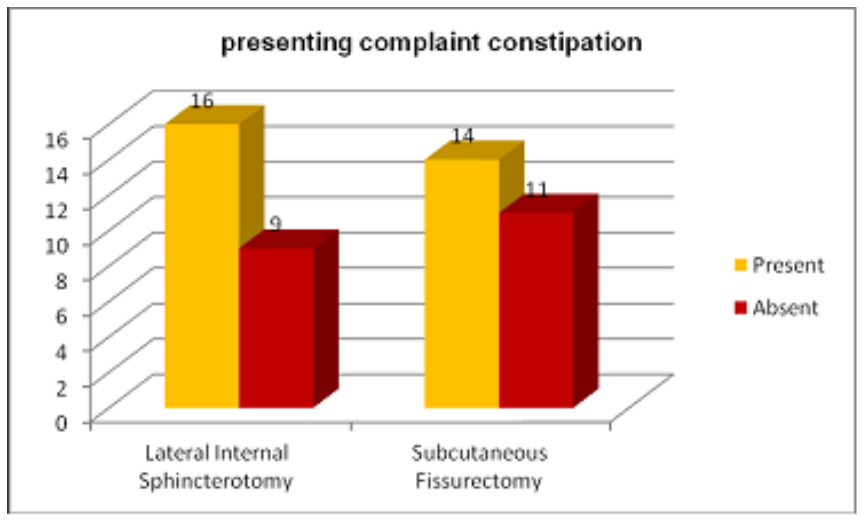

Figure 2: omparison of presenting complaint constipation

fissurectomy, there was no significant difference in presenting complaint in either group [Figure 2].

\begin{tabular}{|lll|}
\hline Table 3: Comparison of patients based on site of fissure in ano \\
\hline $\begin{array}{l}\text { Position of fis- } \\
\text { sure }\end{array}$ & $\begin{array}{l}\text { Lateral Internal } \\
\text { Sphincterotomy } \\
\text { No }(\%)\end{array}$ & $\begin{array}{l}\text { Subcutaneous } \\
\text { Fissurectomy } \\
\text { No \% }\end{array}$ \\
Posterior & $15(60)$ & $16(64)$ \\
Anterior & $10(40)$ & $9(36)$ \\
\hline
\end{tabular}

[Table 3] shows that $80 \%$ of cases who underwent lateral internal sphincterotomy had fissure in the posterior wall and $20 \%$ cases had fissure in the anterior wall compared to $84 \%$ of cases who underwent subcutaneous fissurectomy, had fissure in the posterior wall and $16 \%$ cases had fissure in the anterior wall there was no significant difference in position of fissure in either groups $(\mathrm{p}=0.713)$.

In the present study all the patients were followed up after 6 months, pain score was evaluated using VAS it was observed that mean pain score was 0.4 in cases who underwent lateral internal sphincterotomy compared to 0.24 in cases who underwent subcutaneous fissurectomy, though the mean pain score was lower in patients who underwent

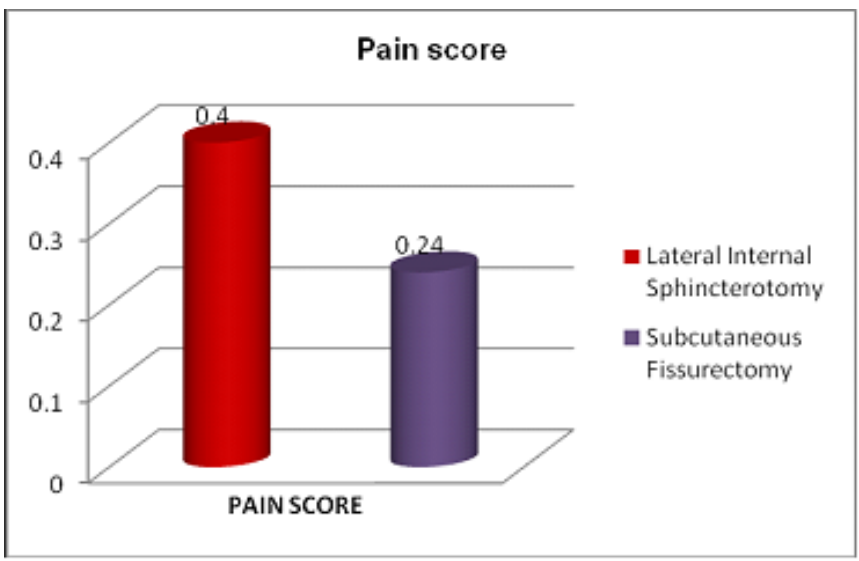

Figure 3: Comparison of main score in patients after 6 months follow up

subcutaneous fissurectomy this decrease in mean pain score was not statistically significant $\mathrm{p}=0.34$ [Figure 3].

All the patients were followed up after 6 months it was observed that $84 \%$ of cases who underwent lateral internal sphincterotomy had healing compared to $96 \%$ of cases who underwent subcutaneous fissurectomy, i.e. healing was higher in patients who underwent subcutaneous fissurectomy [Table 4].

In the present study, patients who underwent lateral internal spincterotomy showed a higher mean duration of absenteeism 3.08 weeks when compared to patients who underwent subcutaneous fissurectomy 0.76 weeks. The duration of absenteeism was significantly higher in patients who underwent lateral internal spincterotomy $\mathrm{p}<0.001$ [Table 5].

\section{Discussion}

In year 1818 for the first time, Boyer suggested sphincterotomy as a treatment of anal fissures. ${ }^{[3]}$ Later on, several surgical techniques (fissurectomy, anal dilation, posterior and lateral sphincterotomy and advanced flap) have been performed for management of CAF. ${ }^{[4]}$

The overall incidence of posterior anal fissure was found to be $80 \%$ making it the most common site involved. Anterior anal fissure was noted in $20 \%$ of patients. This is in conjunction with the study from Boulous which says posterior fissure $(85.7 \%)$ is more common than anterior fissure $(14.2 \%){ }^{[5]}$

Twenty five patients underwent subcutaneous fissurectomy, $22(88 \%)$ patients healed completely at the end of 6 weeks, while $24(96 \%)$ fissures healed completely by six months. Out of 25 patients who underwent lateral internal sphincterotomy $18(72 \%)$ fissures healed completely by 6th week, while 21 $(84 \%)$ fissures healed completely by six months. 
Table 4: Comparison of healing in patients after 6 months follow up

\begin{tabular}{|lll}
\hline Healing & $\begin{array}{l}\text { Lateral Internal Sphincterotomy No } \\
(\%)\end{array}$ & Subcutaneous Fissurectomy No (\%) \\
\hline Present & $21(84)$ & $24 .(96)$ \\
Absent & $4(16)$ & $1(4)$ \\
\hline
\end{tabular}

Table 5: Comparison of Mean duration of absenteeism in patients after surgery

\begin{tabular}{|c|c|c|}
\hline Absenteeism & $\begin{array}{l}\text { Lateral Internal } \\
\text { Mean } \pm \text { SD }\end{array}$ & $\begin{array}{l}\text { Subcutaneous Fissurectomy Mean } \pm \\
\text { SD }\end{array}$ \\
\hline Absenteism In weeks & $3.08 \pm 1.2$ & $0.76 \pm 0.66$ \\
\hline t-value & 8.0 & $\mathrm{P}<0.001$ \\
\hline
\end{tabular}

In the lateral internal sphincterotomy group, mean pain score was 3.52 after 6 weeks follow up and Mean pain score was 0.4 after 6 months. Fissure was completely healed in $18(72 \%)$ out of 25 patients by 6 weeks. Scouten WR et al reported pain relief in $98 \%$ of cases after undergoing internal sphincterotomy. ${ }^{[6]}$ Jensen et al have reported a healing rate of $100 \%$ and Evans et al and Wiley et al have reported healing rate of $97 \%$ with lateral internal sphincterotomy. ${ }^{[7-9]}$

In the subcutaneous fissurectomy group, mean pain score was 2.64 by the end of 6th week and 0.24 by the end of six months. Fissure was completely healed in $22(88 \%)$ out of 25 patients by 6 weeks and $24(96 \%)$ at the end of six months. Subcutaneous fissurectomy is novel procedure; there are no studies available in this aspect.

There is no incontinence in subcutaneous fissurectomy group; transient incontinence for flatus was present in 2(4\%) patients of the lateral internal sphincterotomy group. Adriano Tocchhi et al. report no long-term complication after internal sphincterotomy. ${ }^{[10]}$ There was no recurrence in the subcutaneous fissurectomy group; but in $1(2 \%)$ recurrence occurred in the lateral internal sphincterotomy group.

In the present study, patients who underwent subcutaneous fissurectomy require sitz bath for a mean duration of 0.4 weeks when compared to patients who underwent lateral internal spincterotomy (2.4 weeks). Patients who underwent subcutaneous fissurectomy showed a higher mean duration of absenteeism 0.7 weeks when compared to patients who underwent lateral internal spincterotomy subcutaneous fissurectomy 3.08 weeks. Comparison between subcutaneous fissurectomy and lateral internal sphincterotomy showed a difference in pain relief $(\mathrm{P}=0.17)$, complications $(\mathrm{P}=0.03)$, mean duration of sitz baths $(\mathrm{P}<0.01)$, absenteeism $(\mathrm{P}<0.01)$ which was statistically significant.

The mean pain score decreased from $8.12 \pm 1.33$ to $0.34 \pm 0.74$ in patients treated with fissurectomy and from $8.44 \pm 1.19$ to $0.24 \pm 1.20$ in patients treated surgically with lateral internal sphincterotomy at the end of six weeks. The decrease in mean pain score in group B (lateral internal sphicterotomy) as compared to group A (fissurectomy) at the end of 6 weeks was not statistically significant $(\mathrm{p}>0.001)$.

In this study showed that the lower rate of distressing complications, especially incontinence, and greater satisfaction of the patients, lateral internal sphincterotomy could be considered as a better alternative, sphincter-saving, and perhaps preferable approach in the surgical management of chronic anal fissures.

\section{Conclusion}

The current study shows results in favor of subcutaneous fissurectomy with a healing rate of $100 \%$ with faster painrelief and minimal or no complications if performed by the hands of an experienced surgeon. By comparing the above two modalities of treatment for chronic anal fissure, we conclude that subcutaneous fissurectomy is a better line of treatment in terms of faster pain relief, lesser complications, less mean duration of sitz baths and less absenteeism.

\section{References}

1. Villalba H. Anal Fissure: A Common Cause of Anal Pain. Permanente J. 2007;11(4):62-65. Available from: https://dx. doi.org/10.7812/tpp/07-072. doi:10.7812/tpp/07-072.

2. McCallion K, Gardiner KR. Progress in the understanding and treatment of chronic anal fissure. Postgraduate Med J. 2001;77(914):753-758. Available from: https://dx.doi.org/10. 1136/pgmj.77.914.753. doi:10.1136/pgmj.77.914.753.

3. McNamara MJ, Percy JP, Fielding IR. A Manometric Study of Anal Fissure Treated by Subcutaneous Lateral Internal Sphincterotomy. Annf Surg. 1990;211(2):235238. Available from: https://dx.doi.org/10.1097/00000658199002000-00017. doi:10.1097/00000658-199002000-00017.

4. Nelson RL. Meta-analysis of operative techniques for fissureinano. Dis Colon Rectum. 1999;42:1424-1428.

5. Boulos PB, Araujo JGC. Adequate internal sphincterotomy for chronic anal fissure: Subcutaneous or open technique? $\mathrm{Br} \mathrm{J}$ Surg. 1984;71(5):360-362. Available from: https://dx.doi.org/ 10.1002/bjs.1800710517. doi:10.1002/bjs.1800710517. 
6. Schouten WR, Briel JW, Auwerda JJA, de Graaf EJR. Ischaemic nature of anal fissure. Br J Surg. 1996;83(1):63-65. Available from: https://dx.doi.org/10.1002/bjs.1800830120. doi:10.1002/bjs. 1800830120 .

7. Jensen SL, Lund F, Nielsen OV, Tange G. Lateral subcutaneous sphincterotomy versus anal dilatation in the treatment of fissure in ano in outpatients: a prospective randomised study. Br Med J. 1984;289(6444):528-530. Available from: https://dx.doi.org/ 10.1136/bmj.289.6444.528. doi:10.1136/bmj.289.6444.528.

8. Evans J, Luck A, Hewett P. Glyceryl trinitrate vs. lateral sphincterotomy for chronic anal fissure. Dis Colon Rectum. 2001;44(1):93-97. Available from: https://dx.doi.org/10.1007/ bf02234828. doi:10.1007/bf02234828.

9. Wiley M, Day P, Rieger N, Stephens J, Moore J. Open vs. Closed Lateral Internal Sphincterotomy for Idiopathic Fissurein-Ano: A Prospective, Randomized, Controlled Trial. Dis Colon Rectum. 2004;47(6):847-852. Available from: https:// dx.doi.org/10.1007/s10350-004-0530-2. doi:10.1007/s10350004-0530-2.

10. Tocchi A, Mazzoni G, Miccini M, Bettelli E, Brozzetti S, Cassini D. Total lateral sphincterotomy for anal fissure. Int $\mathbf{J}$
Colorectal Dis. 2004;19(3):245-249. Available from: https:// dx.doi.org/10.1007/s00384-003-0525-9. doi:10.1007/s00384003-0525-9.

Copyright: (c) the author(s), 2020. It is an open-access article distributed under the terms of the Creative Commons Attribution License (CC BY 4.0), which permits authors to retain ownership of the copyright for their content, and allow anyone to download, reuse, reprint, modify, distribute and/or copy the content as long as the original authors and source are cited.

How to cite this article: Reddy V S, Prasad B R, Mohan C R, Chandra B V, Dev S. A Comparative Study of Efficacy of Outcome of Lateral Internal Sphincterotomy versus Subcutaneous Fissurectomy in Chronic Fissure in Ano. Acad. J Surg. 2020;3(1): 59-63.

DOI: dx.doi.org/10.47008/ajs/2020.3.1.13

Source of Support: Nil, Conflict of Interest: None declared. 